\title{
FAKTOR ASPEK LEGAL DOMINAN YANG MEMPENGARUHI PROYEK KONSTRUKSI DI PEDESAAN
}

\author{
Rian Heriawan ${ }^{1}$, Basuki Anondho \\ ${ }^{1}$ Program Studi Sarjana Teknik Sipil, Universitas Tarumanagara, Jl. Letjen S. Parman No.1 Jakarta \\ Email: Rian.325130161@stu.untar.ac.id \\ ${ }^{2}$ Program Studi Sarjana Teknik Sipil, Universitas Tarumanagara, Jl. Letjen S. Parman No.1 Jakarta \\ Email: basukia@ft.untar.ac.id
}

\begin{abstract}
ABSTRAK
Pembangunan Nasional telah berlangsung selama lebih dari 70 tahun sejak Indonesia merdeka, Namun proses pembangunan yang dilaksanakan selama ini masih mengalami masalah kesenjangan khususnya diwilayah pedesaan. Dalam RPJMN (Rencana Pembangunan Jangka Menengah Nasional tahun 2015-2019) dinyatakan bahwa terdapat 122 kabupaten tertinggal. Banyak kendala yang dihadapi dalam proses pembangunan daerah salah satu kendalanya adalah permasalahan hukum yang menghambat laju pembangunan. Penelitian-penelitian yang telah dilakukan sebelumnya menunjukan bahwa permasalahn hukum ini timbul karena beberapa faktor seperti ketidakstabilan sosiopolitik, perekonomian daerah, pendidikan daerah, kualitas lembaga hukum yang buruk. dan keberagaman model lingkungan di setiap daerah. Oleh karena itu, studi ini melakukan penelitian tentang faktor aspek legal dominan yang mempengaruhi proyek konstruksi di pedesaan Indonesia . Penelitian ini dilakukan dengan penyebaran kuesioner kepada sejumlah kontraktor sebagai responden yang mengerjakan proyek dari Kemendes PDTT (Kementrian Desa, Pembangunan Daerah Tertinggal dan Transmigrasi). Analisis data dilakukan dengan menggunakan analisis multivariate yaitu metode analisi faktor yang dimulai dari uji validitas, uji reliabilitas, uji KMO (Kaiser-Mayer-Olkin measure of sampling adequacy), Uji Bartlett's Test Sphericity, dan uji MSA (Measuresof Sampling Adequacy). Hasil dari analisi yang dilakukan menunjukan bahwa perekonomian daerah dan pemilihan pemenag lelang menjadi memiliki pengaruh yang signifikan terhadap laju pembangunan daerah tertinggal.
\end{abstract}

Kata kunci: pembangunan desa tertinggal, aspek legal, Kemendes PDTT, analisis multivariate

\section{PENDAHULUAN}

Pembangunan Nasional telah berlangsung selama lebih dari 70 tahun sejak Indonesia merdeka, Namun proses pembangunan yang dilaksanakan selama ini masih mengalami masalah kesenjangan khususnya diwilayah perdesaan. Kesenjangan ini pada akhirnya menimbulkan permasalahan yang sangat merugikan proses pembangunan yang ingin dicapai. Permasalahan ini disebabkan oleh alokasi sumberdaya yang berlebihan pada wilayah tertentu yang menjadi pusat-pusat pertumbuhan, sedangkan daerah yang tidak mendapat alokasi sumberdaya yang cukup menjadi daerah tertinggal. Daerah tertinggal menurut Peraturan Presiden Nomor 131/2005 Tahun 2015 adalah daerah kabupaten yang wilayah serta masyarakatnya kurang berkembang dibandingkan dengan daerah lain dalam skala nasional. Dalam RPJMN (Rencana Pembangunan Jangka Menengah Nasional tahun 2015-2019) dinyatakan bahwa terdapat 122 kabupaten tertinggal, dimana 103 diantaranya terdapat di kawasan timur Indonesia.

Selain permasalahan alokasi dana, terhambatnya pembangunan diwilayah perdesaan tidak lepas dari permasalahan hukum kontruksi yang terjadi. Selama kurun waktu 2010-2014 pemerintah telah mengidentifikasi beberapa permasalahan pembangunan yang terkait dengan hukum konstruksi yang ditulis didalam rencana strategis pembangunan daerah tertentu 2015-2019. Di antaranya adalah belum optimalnya kebijakan yang mendukung bagi percepatan pembangunan daerah tertinggal, dan adanya regulasi yang tidak memihak terhadap percepatan pembangunan daerah. Terdapat juga beberapa penelitian terkait faktor hukum yang mempengaruhi pelaksanaan konstruksi salah satunya "Political Risks in Central Asian Countries:Factors and Strategies" yang dibuat oleh TengyuanChang pada tahun 2018. Pada penelitiannya Chang menyebutkan ada beberapa faktor hukum yang mempengaruhi pelaksanaan konstruksi diantaranya adalah stabilitas sosiopolitik, kualitas lembaga, dan kebijakan ekonomi.

Di sisi lain, program PDTu, memiliki banyak sekali pembangunan proyek konstruksi di desa tertentu yang harus dibangun. Sehingga, pengetahuan tentang faktor aspek legal dominan yang mempengaruhi proses pelaksanaan konstruksi dapat membantu manajemen proyek untuk mencapai tujuan pelaksanaan proyek.Berdasarkan studi 
textbook dan jurnal telah diidentifikasi beberapa faktor aspek legal dominan yang menjadi variabel dalam penelitian ini.

\section{Studi Pustaka}

1. Rencana Strategis Pengembangan Daerah Tertentu 2015-2019 (RENSTRA 2015-2019)

Pemerintah telah menetapkan 122 daerah tertinggal menjadi prioritas yang tertuang dalam RENSTRA 20152019 (Rencana Strategis Pembangunan Daerah Tertentu). Pembangunan Nasional telah berlangsung selama lebih dari 70 tahun sejak Indonesia merdeka, Namun proses pembangunan yang dilaksanakan selama ini masih mengalami masalah kesenjangan khususnya diwilayah perdesaan. Namun permasalahan pembangnan yang masih dihadapi hingga saat ini yaitu sebagian besar kabupaten masih tertinggal dan persoalan adanya esenjangan antarwilayah. Hal ini tidak sejalan dengan orientasi pembangunan Indonesia kedepan untuk mewujudkan pembangunan yang adil dan merata. Oleh karena itu, pembangunan daerah tertinggal pada periode tahun 20152019 akan difokuskan pada penanganan beberapa permasalahan sebagai berituk :

1. Kesenjangan pembangunan antarwilayah

2. Masih adanya ketidakmerataan pembangunan dan keadilan hasil-hasil pembangunan

3. Terbatasnya ketersediaan sarana dan prasarana public dasar di daerah tertinggal

4. Masih rendahnya kualitas sumber daya manusia dan tingkat kesejahteraan

5. Rendahnya produktivitas masyarakat di daerah tertinggal

6. Lemahnya sendi-sendi perekonomian bangsa terlihat dari belum terselesaikannya persoalan kemiskinan, kesenjangan social, dan kesenjangan antarwilayah

7. Adanya regulasi yang tidak memihak/disharmonis terhadap percepatan pembangunan daerah tertinggal

8. Belum optimalnya kebijakan yang afirmatif bagi percepatan pembangunan daerah tertinggal

9. Masih lemahnya koordinasi antar pelaku pembangunan untuk percepatan pembangunan daerah tertinggal

10. Belum optimalnya pengelolaan potensi sumberdayalocal dalam pengembangan perkonomian di daerah tertinggal

\section{A Guide tothe Project Management Body of Knowledge $6^{\text {th }}$}

Pada PMBOK $6^{\text {th }}$ di jelaskan bahwa ada beberapa faktor aspek legal yang berhubungan dengan keberhasilan proyek seperti komitmen antar pihak, kejelasan ruang lingkup, kejelasan penyelesaian sengketa, pengaruh hubungan baik antar pihak, dan lain sebagainya. Komitmen antar pihak terkait dalam suatu proyek sangat penting karena berhubungan dengan kelancaran pelaksanaan proyek sesuai dengan kontrak. Komitmen antar pihak ini harus didukung dengan hubungan interaktif yang baik agar menjaga pehamaan semua pihak yang terlibat selama pelaksanaan proyek dalam memahami ruang lingkup pekerjaan dan tanggung jawab masingmasing.

Namun, setiap proyek bisa mengalami suatu kesalahan dalam proses pengerjaannya baik dari segi teknis maupun non teknis. Oleh karena itu penting untuk menentukan manajemen pengendalian risiko yang telah disepakati oleh semua pihak. Dalam menentukan manajemen pengendalian risiko keterlibatan pemerintah daerah sebagai pemilik proyek pembangunan di pedesaan sangat penting untuk guna menyelaraskan peraturan daerah yang berlaku dan memberi kebijakan untuk proyek yang akan dikerjakan. Maka untuk membuat manajemen pengendalian risiko yang baik tidak terlepas dari pembuatan kontrak yang baik dan jelas, dimanadidalamnya terdapat klausa penyelesaian sengketa untuk digunakan sebagai jalur penyelesaian permasalahan apabila pihakpihak yang berkepentingan dalam proyek tersebut mengalami masalah satu sama lain.

\section{Studi Jurnal}

1. Risiko Politik di Negara-Negara Asia Tengah: Faktor dan Strategi

2. Menjelajahi Variabel Kritis Yang Mempengaruhi Tingkat Risiko Politik dalam Proyek Konstruksi Internasional: Studi Kasus dari Kontraktor Cina

3. Kesulitan dan Penyaluran Aturan Hukum di Wilayah Pedesaan

4. Manajemen Proyek Jalan Raya di Mesir Melalui Identifikasi Faktor yang Mempengaruhi Kualitas Kinerja

5. Faktor Keberhasilan Proyek Konstruksi jalan Raya di Mesir: Pendekatan AHP

6. Faktor-Faktor yang Mempengaruhi KesuksessanPelaksanan Proyek Jalan Nasional di Maluku

7. Faktor-Faktor yang Mempengaruhi kinerja Proyek: Kasus Proyek Infrastruktur Jalan Pedesaan di Daerah Manyatta

8. Faktor-Faktor yang Mempengaruhi Keberhasilan/Kegagalan Proyek Infrastruktur Jalan di Bawah PPP di India 
Dilakukan identiufikasai awal faktor aspek legal dominan berdsasarkan studi melalui textbook dan jurnal yang disebutukandiatas, sehingga menghasilkan 16 variabel yang merupakan faktor aspek legal yang berpengaruh terhadap pembagunan.

Tabel 1. Identifikasi Variabel

\begin{tabular}{|c|c|c|c|c|c|c|c|c|c|c|c|}
\hline \multirow{2}{*}{ No } & \multirow{2}{*}{ Variabel } & \multicolumn{8}{|c|}{ Jurnal } & \multirow{2}{*}{ RENSTRA } & \multirow{2}{*}{ PMBOK } \\
\hline & & 1 & 2 & 3 & 4 & 5 & 6 & 7 & 8 & & \\
\hline 1 & Stabilitas Sosiopolitik & $\checkmark$ & $\checkmark$ & & & & & $\checkmark$ & $\checkmark$ & $\checkmark$ & \\
\hline 2 & Kualitas Lembaga hukum & $\checkmark$ & $\checkmark$ & $\checkmark$ & & & & & & $\checkmark$ & \\
\hline 3 & Perekonomi daerah & $\checkmark$ & $\checkmark$ & $\checkmark$ & & & $\checkmark$ & $\checkmark$ & & $\checkmark$ & $\checkmark$ \\
\hline 4 & Pendidikan daerah & & & $\checkmark$ & $\checkmark$ & $\checkmark$ & & & & $\checkmark$ & $\checkmark$ \\
\hline 5 & Hubungan interaktif & $\checkmark$ & $\checkmark$ & & & $\checkmark$ & & & & & $\checkmark$ \\
\hline 6 & Pengembangan model hukum & $\checkmark$ & $\checkmark$ & & & $\checkmark$ & & & & & $\checkmark$ \\
\hline 7 & Komitmen semua pihak & & & & & $\checkmark$ & $\checkmark$ & & & & $\checkmark$ \\
\hline 8 & Keselarasan kebijakan & $\checkmark$ & & $\checkmark$ & & $\checkmark$ & $\checkmark$ & & & $\checkmark$ & $\checkmark$ \\
\hline 9 & keselarasan peraturan & & & $\checkmark$ & & & $\checkmark$ & & $\checkmark$ & $\checkmark$ & $\checkmark$ \\
\hline 10 & Kejelasan ruang lingkup & & & & $\checkmark$ & $\checkmark$ & & & $\checkmark$ & & $\checkmark$ \\
\hline 11 & Kejelasan tujuan & & & & $\checkmark$ & $\checkmark$ & & & & & $\checkmark \checkmark$ \\
\hline 12 & Pendanaan proyek & & & & $\checkmark$ & & $\checkmark$ & $\checkmark$ & $\checkmark$ & & $\checkmark$ \\
\hline 13 & Pengendalian risiko & & & & & $\checkmark$ & $\checkmark$ & & & & $\checkmark$ \\
\hline 14 & Pemilihan pemenang lelang & & & & $\checkmark$ & $\checkmark$ & $\checkmark$ & & & & \\
\hline 15 & Keterlibatan pemerintah & & & & $\checkmark$ & $\checkmark$ & & $\checkmark$ & $\checkmark$ & & $\checkmark$ \\
\hline 16 & Penyelesaian sengketa & & & & & $\checkmark$ & & & $\checkmark$ & & $\checkmark$ \\
\hline
\end{tabular}

1. Stabilitas Sosiopolitik

Chang, et al, (2018) dan Deng, etal (2014) menyatakan bahwa risiko geopolitik termasuk konflik antara daerah atau konflik di sekitarnya dapat mempengaruhi stabilitas dan keamanan daerah tersebut. Ketidakstabilan politik seperti konflik etnis dan agama dapat secara langsung atau tidak langsung mempengaruhi konstruksi melalui perubahan hukum, peraturan, dan kebijakan. Proyek yang dilakukan oleh PT pemerintah mungkin menjadi sasaran konflik antar kelompok. Selain itu, ketidakstabilan pemerintah sering mengakibatkan kemunduran masyarakat, yang menghadirkan ancaman signifikan bagi keamanan pelaksanaan konstruksi. Karena kondisi proyek akan terpengaruh lingkungan politik dan hukum yang berlaku (Mwakajom, etal, 2017) dan adanya protes dan oposisi publik terhadap proyek pembangunan yang di anggap tidak sesuai (Nallathiga, etal, 2017). Opisisi piblik biasanya timbul dari penduduk miskin yang tidak memiliki aset dan terkena dampak dari pembangunan daerah (RENSTRA).

\section{Kualitas Lembaga Hukun}

Chang, et al, (2018) dan Deng, etal, (2014) menyatakan bahwa lembaga hukum yang mewakili kemampuan pemerintah dituntut untuk menyediakan aturan kegiatan bisnis konstruksi yang baik dan menciptakan lingkungan administrasi yang baik. Kualitas institusi yang buruk seperti kinerja yang buruk dalam peraturan, pemerintah yang tidak efisien, kontrol korupsi yang buruk, serta tidak dapat menjamin hak dan kepentingan kontraktor. Hal ini dapat menyebabkan kontraktor kehilangan kepercayaan pada sistem peradilan dan memaksa kontraktor untuk memilih cara lain, seperti penyuapan untuk menyelesaikan masalah. Sehingga kontraktor yang berada dilingkungan dengan penegakan hukum yang buruk akan menderita kerugian seperti pelanggaran kontrak, penyuapan, dan korupsi. Dalam RENSTRA dijelaskan bahwa adanya regulasi yang disharmonis, sehingga perlu dilakukan revisi agar regulasi tersebut sejalan dengan upaya percepatan pembangunan daerah tertinggal, hal ini menunjukan kualitas lembaga hukum dalam menetapkan peraturan yang berlaku.

\section{Perekonomian Daerah}

Thianchong, etal, (2014) menyatakan bahwa basis ekonomi menentukan struktur atas yang dikenal sebagai teori filsafat. Begitu banyak orang yang berpikir bahwa pengembangan aturan hukum di daerah pedesaan adalah hal yang paling penting untuk perkembangan pembangunan dan ekonominya. Kita tahu bahwa untuk 
mengembangkan aturan hukum di pedesaan pertama kita harus membangunan ekonomi pedesaan. Jadi pemerintah harus lebih berupaya dalam hal ini, perencanaan menyeluruh untuk pengembangan ekonomi pedesaan, mengatur pasar ekonomi pedesaan, upaya untuk meningkatkan standar hidup pedesaan. Dan Chang, etal, (2018) dan Deng, etal, (2014) menyatakan bahwa perekonomi daerah merupakan sumber risiko politik yang penting. Tingkat pertumbuhan ekonomi yang tinggi mewakili permintaan besar untuk pembangunan. Sebaliknya, perekonomi yang buruk seperti tingkat pertumbuhan yang rendah dan tingkat pengangguran yang tinggi, dapat mengakibatkan risiko politis, seperti pemberontakan masyarakat terhadap pemerintah dan kerusuhan sosial yang merugikan lingkungan. Sehingga menghambat pembangunan daerah.

\section{Pendidikan Daerah}

Tianchong, etal,(2014) menyatakan bahwa dalam empat tahun terakhir dalam kegiatan mempopulerkan hukum telah membuat kemajuan yang baik. Namun, masih ada beberapa kekurangan, seperti pengetahuan hukum didaerah tidak terlalu baik untuk beberapa undang-undang dan peraturan yang terkait dengan kepentingan vital pembangunan. Dan teori hukum terlalu abstrak dan tidak memperhatikan kemampuan pelaksana. Jadi untuk daerah pedesaan tanpa pelatihan hukum yang efektif, itu akan membawa banyak konsekuensi yang tidak menguntungkan. Contohnya tingkatkan kesadaran dan pemahaman akan pentingnya kualitas kontruksi (Matty, etal, 2016) didesa masih kyrang diperhatikan oleh kontraktor

\section{Hubungan Interaktif}

Chang, et al, (2018) dan Deng, etal, (2014) menyatakan bahwa hubungan interaktif antara pemerintah dan pelaksana pembangunan memainkan peran penting dalam bisnis konstruksi. Hubungan yang baik antara pemerintah dan kontraktor akan dapat menghasilkan kemudahan operasi kontraktor didaerah tersebut melalui sikap yang baik dan kebijakan yang menguntungkan bagi kontraktor. Sebaliknya, hubungan yang memburuk akan mengurangi peluang dan meningkatkan risiko politik untuk kontraktor. Kontraktor dapat menerima lebih banyak dukungan dari pemerintah dan yang lebih besar rasa penerimaan dari masyarakat ketika mereka beroperasi didaerah yang memiliki hubungan baik. Contohnya dalam pelaksanaan proyek sering rapat di antara pihak bekepentingan untuk mengevaluasi kinerja (Maaty, etal, 2016). Hal ini merupakan gambaran hubungan interaktif antar pihak yang berkepentingan dalam suatu proyek.

\section{Pengembangan Model Hukum}

Chang, et al, (2018) dan Deng, etal, (2014) menyatakan bahwa perusahaan dapat dipengaruhi oleh peristiwa politik dengan berbagai cara tergantung pada karakteristik unik mereka. Hubungan dengan pemerintah, kelompok-kelompok kekuasaan (mis., Serikat pekerja, asosiasi bisnis, kelompok perlindungan lingkungan dan aktivis publik dapat menjadi aset atau kewajiban bagi kontraktor. Hubungan dapat membentuk lingkungan politik dan sosial di mana kontraktor beroperasi. Hubungan yang baik dan kuat dengan pemerintah daerah, kelompok-kelompok kekuasaan, dan masyarakat menciptakan lingkungan yang menguntungkan bagi kontraktor, sementara sikap negatif meningkatkan kemungkinan dampak negatif pada kontraktor. Untuk membentuk lingkungan yang baik maka perlu engembangkan hubungan persahabatan yang positif antar pihak (Maaty, etal, 2016). Pengetahuan dan pengalaman sangat penting dalam proses pengambilan keputusan perusahaan.

\section{Komitmen Semua Pihak}

Chang, etal, (2018) menyatakan bahwa status kontraktor yang baik di suatu daerah akan sangat mendukung. Kontraktor yang memiliki status yang baik akan menerima lebih banyak perhatian dan harapan yang lebih tinggi dari pemerintah dan publik, yang berarti mendapat kan banyak dukungan seperti pendanaan yang cukup dan persetujuan yang mudah. Sedangkan kontraktor yang memiliki status kurang baik akan mendapatkan kesulitan seperti poenangguhan pembayaran dan persetujuan yang sulit. Oleh karena itu komitmen semua pihak yang berkepentingan harus di jaga (Maaty, etal, 2016) dan (Zachawerus, etal, 2018).

\section{Keselarasan Kebijakan}

Dalam RENSTRA 2015-2019 dijelasakan bahwa selama kurun waktu 2010-2014 masih banyak permasalahan pembangunan yang dihadapi. Salah satunya adalah belum optimalnya kebijakan yang afirmatif bagi percepatan pembangunan daerah tertinggal. Pembangunan daerah tertinggal harus dilaksanakan secara lebih focus dan komperhensif serta adanya keberpihakan (afirmasi) baik dari aspek kebijakan, perencanaan, dan penganggaran. Belum optimalnya kebijakan yang afirmatif terhadap percepatanm pembangunan daerah tertinggal menjadi kendala tersendiri dalam memobilisasi sumberdaya pembangunan juntuk diarahkan ke daesrah tertinggal.

\section{Keselarasan Peraturan}

Dalam RENSTRA 2015-2019 dijelasakan juga selain permasalahdiatas ada satu poermasalah terkait hukum dan peraturan, yaitu adanya regulasi yang tidak memihak/disharmonis terhadap percepatan pembangunan daerah tertinggal. Masalah ini menimbulkan disharmonis antar kebijakan, inesfisiensi, dan kontra produktif, sehingga 
upaya akselerasi atau percepatan pembangunan daerah tertinggal menjadi terhambat. Oleh karena itu, perlu adanya revisi terhadap beberapa regulasi yang tidak sejalan dengan upaya percepatan pembangunan derah tertinggal.

\section{Kejelasan Ruang Lingkup}

Maaty, et al, (2016) dan Nallathiga, etal, (2017) menyatakan bahwa kualitas konstruksi adalah produk upaya tim dan itu adalah tanggung jawab pemilik, kontaktor, konsultan, dan salah satu staf mereka yang mungkin terlibat. Selama proses konstruksi, setiap tim memiliki peran khusus untuk dimainkan dalam memastikan kualitas proyek. Identifikasi yang jelas dari otoritas, tanggung jawab, dan peran masing-masing pihak dalam klausul kontrak akan meminimalkan kesalahpahaman dan konflik antara para pemangku kepentingan proyek, dan akibatnya, ini akan mengarah pada kerja sama antara pihak-pihak proyek di mana upaya lebih difokuskan pada membangun proyek sesuai dengan tingkat kualitas yang diinginkan.

\section{Kejelasan Tujuan}

Maaty, etal, (2016) menyatakan bahwa dokumen tender yang baik dapat menggambarkan spesifikasi yang baik sesuai dengan tujuan proyek dan kejelasan peran dan tanggung jawab masing-masing pihak. Sehingga, kesalahpahaman, konflik dan perselisihan antara para pemangku kepentingan proyek akan diminimalkan dan ini akan mengarah pada kerja sama antara pihak-pihak proyek di mana upaya difokuskan pada pencapaian tingkat kualitas yang diinginkan dan menyelesaikan proyek sesuai dengan jadwal waktu dan anggaran yang direncanakan.

\section{Pendanaan Proyek}

Mwakajo, etal, (2017) menyatakan bahwa pendanaan proyek adalah faktor dasar pelaksanaan tugas berkontribusi terhadap kecukupan dalam pelaksanaan kegiatan. Pengaturan anggaran ditemukan menjadi faktor penting dalam melakukan eksekusi. Dengan mempertimbangkan semuanya, pembiayaan yang memadai memiliki pengaruh paling besar terhadap penggunaan kegiatan. Nallathiga, etal, (2017) menyatakan bahwa menurut pemerintahm, konsultan, dan kontraktor faktor yang paling berpengaruh atas keberhasilan/ kegagalan proyek adalah pemasukan dana kedalam proyek dan keterlambatan pembayaran kepada kontraktor. Namun sistem birokkrasi yang rumit dapat mempengaruhi kelancaran dana proyek. Hal ini di kemukakan oleh James KiraguNduati (2017) dalam penelitiannya bahwa sifat birokrasi dalam manajemen dan implementasi proyek menyebabkan keterlambatan dalam proyek pembangunan.

\section{Pengendalian Risiko}

Maaty, et al, (2016) menyatakan bahwa menetapkan sistem manajemen risiko formal dalam kontrak yang mengklarifikasi identifikasi dan alokasi risiko merupakan faktor yang berpengaruh dalam mengatasi risiko yang akan dihadapi dalam pelaksanaan proyek konstruksi. Zachawerus,etal, (2017) dalam penelitiannya menyatakan Pengendalian risiko yang tercantum dalam kontrak dapat mempengaruhi pengambilan keputusan.

\section{Pemilihan Pemenang Lelang}

El-Maaty, etal, (2016) menyatakan bahwa ada beberapa faktor dalam pemilihan kontraktor, salah satunya adalah pemilihan penawar terendah untuk membangun proyek. Namun, dengan memperbaiki prosedur pemberian kontrak dengan memberikan bobot lebih sedikit pada harga dan lebih banyak bobot pada kemampuan, kondisi keuangan, dan kinerja kontraktor di masa lalu akan berdampak positif pada kinerja proyek.

\section{Keterlibatan Pemerintah}

Mwakajo, etal, (2017) menyatakan bahwa harus ada upaya khusus oleh pemimpinan daerah untuk memberikan kepemimpinan langsung dari tingkat akar rumput. Semua pemangku kepentingan utama perlu dilibatkan sejak survei awal hingga tahap perencanaan dan implementasi proyek. Sebelum dimulainya proyek, tim proyek harus melakukan upaya untuk memobilisasi sumber daya yang diperlukan, baik sumber daya keuangan dan manusia untuk memungkinkan kelancaran arus operasi.

\section{Penyelesaian Sengketa}

Nallathiga, etal, (2017) meyatakan bahwa faktor yang bertanggung jawab atas kegagalan proyek adalah ketidaklengkapan konsesi / kontrak, seperti klausul pemutusan dll. El-Maaty, etal, (2016) juga mendukung pernyataan ini dengan menyatakan bahwa salah satu faktor yang berpengaruh terhadap proyek adalah adanya klausul resolusi perselisihan yang tepat dimasukkan dalam kontrak. 


\section{METODOLOGI PENELITIAN}

Langkah-langkah penelitian berupa diagram alir yang dilakukan dapat dilihat pada diagram berikut ini:

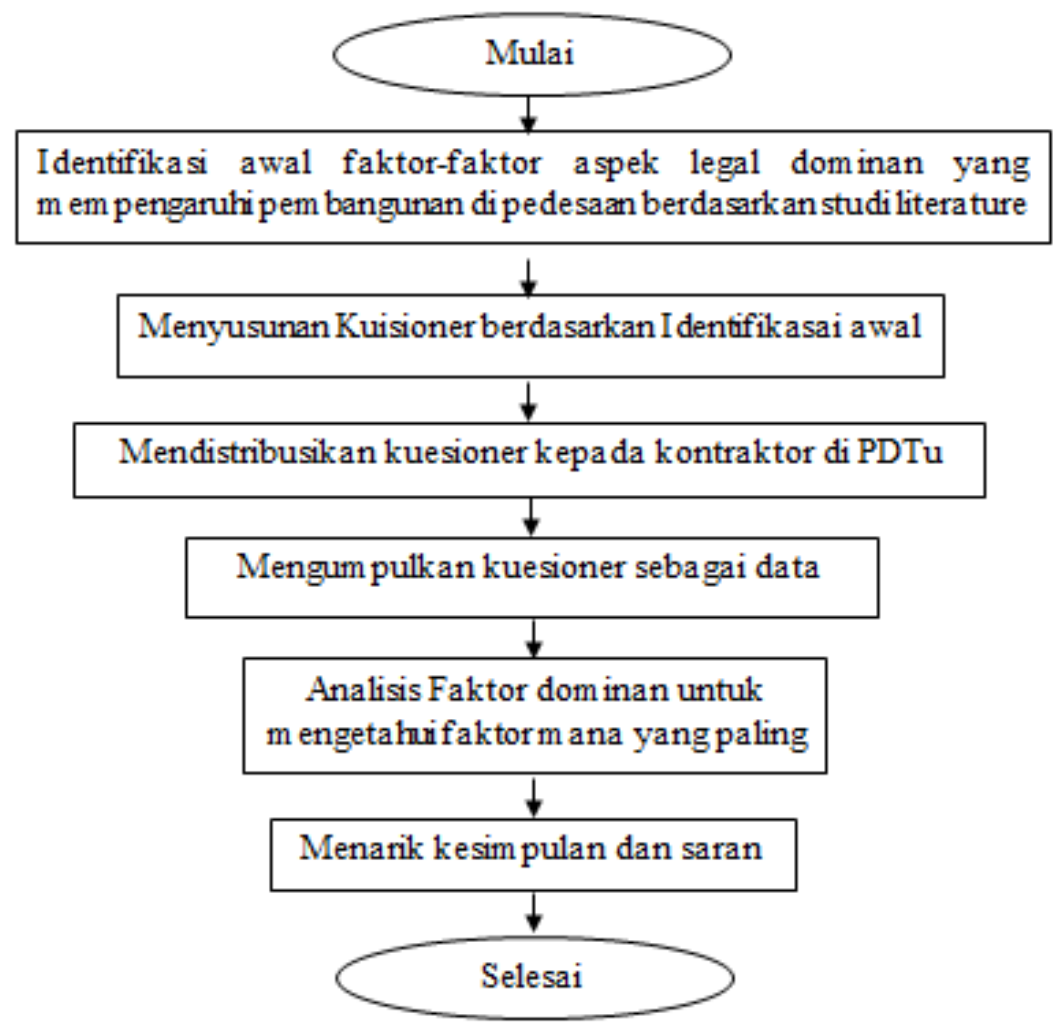

Gambar 1. Diagram Alir Penelitian

\section{Penyusunan Kuesioner}

Dalam penelitian ini instrumen penelitian yang diguunakan adalah kuesioner. Penggunaan kuesioner lebih tepat dilakukan di pedesaan dalam melakukan penelitian dibandingkan dengan wawancara dan sejenisnya.

1. Dapat disebarkan untuk responden yang berjumlah besar dengan waktu yang relatif singkat.

2. Karena diformat dalam bentuk surat, maka biaya lebih murah.

3. Penggunaan waktu yang relatif fleksibel sesuai dengan waktu yang telah diberikan peneliti.

4. Dapat menjaring informasi dalam skala luas dengan waktu yang cepat.

Kuesioner dibuat dengan menggunakan skala Likert. Pada kuesioner ini skala likert dengan nilai 1 (satu) merupakan nilai minimal (tidak setuju) sampai dengan nilai 5 (lima) merupakan nilai maksimum (sangat setuju).

\section{Pengumpulan Data}

Kuesioner ini disebarkan/ didistribusikan kepada responden yang terlibat dengan proyek konstruksi infrastruktur desa, yaitu kontraktor dari KemendesPDTu untuk mengumpulkan data-data proyek dan hasil jawaban kuesioner yang diperlukan untuk mengola data.Populasi dalam penelitian ini adalah para kontraktor yang bekerja dalam proyek konstruksi serta berada di kawasan pedesaan Indonesia. Sampel pada penelitian ini diambil 50 responden.

\section{Pengujian Instrumen}

\section{Uji Validitas}

Tujuan uji validitas adalah untuk mengetahui valid atau tidaknya suatu data kuesioner yang diperoleh dari survei. Data dikatakan valid jika ada korelasi dengan skor total. Syarat pengujian adalah nilai pearsoncorrelation $>\mathrm{r}_{\text {tabel }}$ 


\section{Uji Reliabilitas}

Reliabilitas adalah pengujian yang bertujuan untuk mengetahui sejauh mana pengukuran dari suatu tes tetap konsisten setelah dilakukan berulang-ulang terhadap subjek dan dalam kondisi yang sama. Penelitian dianggap dapat diandalkan bila memberikan hasil yang konsisten untuk pengukuran yang sama.

\section{Pengujian Data}

\section{Uji Kaiser-Mayer-Olkin measure of sampling adequacy}

Kaiser-Mayer-Olkin measure of sampling adequacy (KMO) digunakan untuk menguji kecukupan sampel dalam penelitian analisis faktor. Jika KMO lebih besar dari 0,5, maka diindikasikan jumlah sampel cukup memenuhi untuk digunakan dalam analisis faktor.

\section{UJiBartlett's Test Sphericity}

Bartlett's Test Sphericity, digunakan untuk menunjukkan korelasi antara variabel secara keseluruhan. Jika signifikansi kurang dari 0,05 menunjukkan adanya korelasi antara variabel secara keseluruhan

\section{Uji Measureof Sampling Adequancy}

Measuresof Sampling Adequacy (MSA), jika nilai MSA setiap variabel lebih besar dari 0,5, maka diindikasikan jumlah sampel cukup untuk digunakan di dalam analisis faktor. MSA digunakan untuk menguji kecukupan variabel yang digunakan untuk analisis faktor.

\section{Uji Komunalitas}

Komunalitas (communalities), tabel communalities menjelaskan bahwa pada dasarnya adalah jumlah varian (bisa dalam presentase) suatu variabel yang mula-mula bisa dijelaskan oleh faktor yang ada. Ketentuannya adalah makin besar communalities sebuah variabel, berarti makin erat hubungannya dengan faktor yang terbentuk. Nilai extraction uji komunalitas $>0,5$. Jika variabel dengan nilai extraction< 0,5, maka variabel tersebut harus dikeluarkan dan melakukan pengujian ulang.

\section{HASIL DAN PEMBAHASAN}

\section{Uji Validitas}

Dalam penelitian ini seluruh variabel yang diuji memiliki nilai Pearson correlation $>r_{\text {tabel }}(0.284)$. Maka isntrumen penelitian dinyatakan valid untuk mendapatkan data untuk setiap variabel seperti yang dapat dilihat di tabel.

Tabel 2. Uji Validitas

\begin{tabular}{|c|c|c|c|c|c|}
\hline \multicolumn{6}{|c|}{ Correlations } \\
\hline Kode & Variabel & Keterangan & Total Skor & $\mathrm{r}$ tabel & Hasil \\
\hline \multirow{3}{*}{$\mathrm{A} 1$} & \multirow{3}{*}{ Stabilitas Sosiopolitik } & Pearson Correlation & 0.565 & \multirow{3}{*}{0.284} & \multirow{3}{*}{ VALID } \\
\hline & & Sig. (2-tailed) & 0 & & \\
\hline & & $N$ & 50 & & \\
\hline \multirow{3}{*}{ A2 } & \multirow{3}{*}{$\begin{array}{c}\text { Kualitas Lembaga } \\
\text { Hukum }\end{array}$} & Pearson Correlation & 0.634 & \multirow{3}{*}{0.284} & \multirow{3}{*}{ VALID } \\
\hline & & Sig. (2-tailed) & 0 & & \\
\hline & & $N$ & 50 & & \\
\hline \multirow{3}{*}{ A3 } & \multirow{3}{*}{ Perekonomian Daerah } & Pearson Correlation & 0.722 & \multirow{3}{*}{0.284} & \multirow{3}{*}{ VALID } \\
\hline & & Sig. (2-tailed) & 0 & & \\
\hline & & $N$ & 50 & & \\
\hline \multirow{3}{*}{ A4 } & \multirow{3}{*}{ Pendidikan Daerah } & Pearson Correlation & 0.673 & \multirow{3}{*}{0.284} & \multirow{3}{*}{ VALID } \\
\hline & & Sig. (2-tailed) & 0 & & \\
\hline & & $N$ & 50 & & \\
\hline \multirow{3}{*}{ A5 } & \multirow{3}{*}{ Hubungan Interaktif } & Pearson Correlation & 0.562 & \multirow{3}{*}{0.284} & \multirow{3}{*}{ VALID } \\
\hline & & Sig. (2-tailed) & 0 & & \\
\hline & & $N$ & 50 & & \\
\hline \multirow{3}{*}{ A6 } & \multirow{3}{*}{$\begin{array}{c}\text { Pengembangan Model } \\
\text { Hukum }\end{array}$} & Pearson Correlation & 0.722 & \multirow{3}{*}{0.284} & \multirow{3}{*}{ VALID } \\
\hline & & Sig. (2-tailed) & 0 & & \\
\hline & & $N$ & 50 & & \\
\hline \multirow{3}{*}{ A7 } & \multirow{3}{*}{$\begin{array}{c}\text { Komitmen Semua } \\
\text { Pihak }\end{array}$} & Pearson Correlation & 0.558 & \multirow{3}{*}{0.284} & \multirow{3}{*}{ VALID } \\
\hline & & Sig. (2-tailed) & 0 & & \\
\hline & & $N$ & 50 & & \\
\hline
\end{tabular}


Faktor Aspek Legal Dominan yang Mempengaruhi Proyek

Rian Heriawan, et.al. Konstruksi di Pedesaan

Tabel 2. Uji Validitas (Lanjutan)

\begin{tabular}{|c|c|c|c|c|c|}
\hline \multirow[t]{2}{*}{ A8 } & \multirow[t]{2}{*}{ Keselarasan Kebijakan } & $\begin{array}{c}\text { Pearson Correlation } \\
\text { Sig. (2-tailed) } \\
\end{array}$ & $\begin{array}{c}0.489 \\
0 \\
\end{array}$ & \multirow[t]{2}{*}{0.284} & \multirow[t]{2}{*}{ VALID } \\
\hline & & $N$ & 50 & & \\
\hline \multirow{3}{*}{ A9 } & \multirow{3}{*}{ Keselarasan Peraturan } & Pearson Correlation & 0.491 & \multirow{3}{*}{0.284} & \multirow{3}{*}{ VALID } \\
\hline & & Sig. (2-tailed) & 0 & & \\
\hline & & $N$ & 50 & & \\
\hline \multirow{3}{*}{ A10 } & \multirow{3}{*}{$\begin{array}{l}\text { Kejelasan Ruang } \\
\text { Lingkup }\end{array}$} & Pearson Correlation & 0.386 & \multirow{3}{*}{0.284} & \multirow{3}{*}{ VALID } \\
\hline & & Sig. (2-tailed) & 0.006 & & \\
\hline & & $N$ & 50 & & \\
\hline \multirow{3}{*}{ A11 } & \multirow{3}{*}{ Kejelasan Kontrak } & Pearson Correlation & 0.527 & \multirow{3}{*}{0.284} & \multirow{3}{*}{ VALID } \\
\hline & & Sig. (2-tailed) & 0 & & \\
\hline & & $N$ & 50 & & \\
\hline \multirow{3}{*}{ A12 } & \multirow{3}{*}{ Pendanaan Proyek } & Pearson Correlation & 0.538 & \multirow{3}{*}{0.284} & \multirow{3}{*}{ VALID } \\
\hline & & Sig. (2-tailed) & 0 & & \\
\hline & & $N$ & 50 & & \\
\hline \multirow{3}{*}{ A13 } & \multirow{3}{*}{ Pengendalian Risiko } & Pearson Correlation & 0.504 & \multirow{3}{*}{0.284} & \multirow{3}{*}{ VALID } \\
\hline & & Sig. (2-tailed) & 0 & & \\
\hline & & $N$ & 50 & & \\
\hline \multirow{3}{*}{ A14 } & \multirow{3}{*}{$\begin{array}{l}\text { Pemilihan Pemenang } \\
\text { Lelang }\end{array}$} & Pearson Correlation & 0.705 & \multirow{3}{*}{0.284} & \multirow{3}{*}{ VALID } \\
\hline & & Sig. (2-tailed) & 0 & & \\
\hline & & $N$ & 50 & & \\
\hline \multirow{3}{*}{ A15 } & \multirow{3}{*}{ Keterlibatan Pemda } & Pearson Correlation & 0.323 & \multirow{3}{*}{0.284} & \multirow{3}{*}{ VALID } \\
\hline & & Sig. (2-tailed) & 0.022 & & \\
\hline & & $N$ & 50 & & \\
\hline \multirow{3}{*}{ A16 } & & Pearson Correlation & 0.452 & & \\
\hline & $\begin{array}{c}\text { Kejelasan } \\
\text { Penvelesaian Senoketa }\end{array}$ & Sig. (2-tailed) & 0.001 & 0.284 & VALID \\
\hline & & $N$ & 50 & & \\
\hline
\end{tabular}

\section{Uji Reliabilitas}

Dalam pengujian reliabilitas nilai conbach’s Alpha yang di peroleh adalah 0,850, lebih besar daripada 0,6. Maka instrumen penelitian yang digunakan dinyatakan layak, sehingga data yang di peropleh dapat digunakan dalam analisis faktor.

Tabel 3. Uji Reliabilitas

\begin{tabular}{cc}
\hline \multicolumn{2}{c}{ ReliabilityStatistics } \\
\hline Cronbach'sAlpha & NofItems \\
\hline 0.850 & 16 \\
\hline
\end{tabular}

\section{Uji Kaiser-Mayer-Olkin measureof sampling adequacydan uji Bartlett's Test Sphericity}

Kaiser-Mayer-Olkin measureof sampling adequacy (KMO) pada penelitian ini adalah 0,661 > 0,5, maka sampel dalam penelitian ini dinyataakn cukup dalam melakukan analisi faktor. Dan nilai Bartlett's Test Sphericity sebesar 0,00<0,05, yang berarti adanya korelasi antara variabel secara keseluruhan.

Tabel 4. Uji KMO dan Bartlett Siklus Pertama

\begin{tabular}{lll}
\hline \multicolumn{3}{c}{ KMO and Bartlett'sTest } \\
\hline Kaiser-Meyer-OlkinMeasureof Sampling Adequacy. & 0.661 \\
\hline \multirow{3}{*}{ Bartlett's Test of Sphericity } & Approx. Chi-Square & 430.314 \\
\cline { 2 - 3 } & Sf & 66 \\
\cline { 2 - 3 } & $S$. & 0.000 \\
\hline
\end{tabular}




\section{Uji Measure of Sampling Adequancy}

Hasil dari pengujian Measuresof Sampling Adequacy (MSA) dilakukan 4 kali dikarenakan adabeberapa variabel yang tidak lulus pengujian. Dari 15 variabel awal yang diuji hanya 10 variabel yang lulus pengujian MSA yang dapat dilihat pada diagonal tabel yang memiliki nilai lebih dari 0,5.

Tabel 5. Uji Measureof Sampling Adequancy

\begin{tabular}{ccccccccccccc}
\hline & A2 & A3 & A4 & A5 & A6 & A7 & A9 & A11 & A12 & A14 \\
\hline A2 & $0.892^{\mathrm{a}}$ & 0.067 & -0.229 & -0.149 & -0.081 & -0.102 & -0.098 & 0.022 & 0.132 & -0.244 \\
\hline A3 & 0.067 & $0.821^{\mathrm{a}}$ & -0.499 & -0.161 & -0.083 & 0.059 & -0.204 & 0.165 & -0.210 & -0.284 \\
\hline A4 & -0.229 & -0.499 & $0.776^{\mathrm{a}}$ & 0.014 & -0.190 & -0.141 & 0.317 & -0.239 & 0.211 & -0.174 \\
\hline A5 & -0.149 & -0.161 & 0.014 & $0.729^{\mathrm{a}}$ & 0.068 & 0.114 & 0.039 & -0.224 & -0.305 & 0.025 \\
\hline A6 & -0.081 & -0.083 & -0.190 & 0.068 & $0.915^{\mathrm{a}}$ & -0.020 & -0.020 & -0.148 & -0.110 & -0.298 \\
\hline A7 & -0.102 & 0.059 & -0.141 & 0.114 & -0.020 & $0.778^{\mathrm{a}}$ & -0.219 & 0.226 & -0.385 & -0.151 \\
\hline A9 & -0.098 & -0.204 & 0.317 & 0.039 & -0.020 & -0.219 & $0.724^{\mathrm{a}}$ & -0.208 & 0.037 & -0.224 \\
\hline A11 & 0.022 & 0.165 & -0.239 & -0.224 & -0.148 & 0.226 & -0.208 & $0.564^{\mathrm{a}}$ & -0.288 & 0.091 \\
\hline A12 & 0.132 & -0.210 & 0.211 & -0.305 & -0.110 & -0.385 & 0.037 & -0.288 & $0.598^{\mathrm{a}}$ & 0.056 \\
\hline A14 & -0.244 & -0.284 & -0.174 & 0.025 & -0.298 & -0.151 & -0.224 & 0.091 & 0.056 & $0.872^{\mathrm{a}}$ \\
\hline
\end{tabular}

\section{Uji Komunalitas}

Pengujian terakhir adalah komunalitas (communalities) dalam tabel seluruh variabel memiliki nilai lebih besar dari 0,5 yang berarti seluruh variabel lulus uji komunalitas. Dan dalam pengujian ini dapat kita ketahui peringkat dari variabel yang paling berpengaruh dengan melihat nilai extraction terbesar.

Tabel 6. Uji Komunalitas

\begin{tabular}{llcc}
\hline \multicolumn{4}{c}{ Communalities } \\
\hline Kode & Variabel & Initial & Extraction \\
\hline A2 & Kualitas Lembaga Hukum & 1 & 0.598 \\
\hline A3 & Perekonomian Daerah & 1 & 0.733 \\
\hline A4 & Pendidikan Daerah & 1 & 0.812 \\
\hline A5 & Hubungan Interaktif & 1 & 0.623 \\
\hline A6 & Keberagaman Model & 1 & 0.66 \\
\hline A7 & Komitmen Semua Pihak & 1 & 0.71 \\
\hline A9 & Keselarasan Peraturan & 1 & 0.55 \\
\hline A11 & Kejelasan Kontrak & 1 & 0.625 \\
\hline A12 & Pendanaan proyek & 1 & 0.739 \\
\hline A14 & Pemilihan Pemenang Lelang & 1 & 0.807 \\
\hline & & 1 & \\
\hline
\end{tabular}

\section{KESIMPULAN}

Dari analisis perbandingan perhitungan kapasitas daya dukung fondasi maka dapat ditarik kesimpulan sebagai berikut:

1. Berdasarkan hasil analisis yang dilakukan, maka dapat ditarik kesimpulan yaitu didapatkan 10 (sepuluh) faktor aspek legal dominan yang mempengaruhi proyek konstruksi di pedesaan Indonesia, sebagai berikut: pendidikan daerah, pemilihan pemenang lelang, perekonomian daerah, kualitas lembaga hukum, Pengembangan model hukum, kejelasan kontrak, hubungan interaktif, pendanaan proyek, komitmen semua pihak, dan keselarasan peraturan. 
2. Pentingnya peningkatan pendidikan daerah sehingga timbul pemahaman hukum yang baik dimasyarakat, sehingga tingkat konflik proyek pembangunan seperti pembebasan lahan dan lain sebagainya dapat diturunkan.

\section{DAFTAR PUSTAKA}

Ariftiro, Muhammad. (2006). Analisis faktor. makasar: Andira Publisher

Chang, T., Deng, X., Zuo, J., \& Yuan, J. (2018). Political Risks in Central Asian Countries: Factors and Strategy. 34.

Deng, X., \& Low, S. P. (2014). Exploring Critical Variabes That Affect Political Risk Level in International Construction Projects: Case Study from Chinese Contractors .140.

Direktorat Jendral Pengembangan Daerah Tertentu. (2015). Rencana Strategis Pengembangan Daerah Tertentu 2015-2019. Jakarta: Direktorat Jendral Pengembangan Daerah Tertentu.

Direktorat Jendral Pengembangan Daerah Tertentu. (2017). Riviu Rencana Strategis Pembanguna Deaerah Tertentu 2015-2019. Jakarta : Direktorat Jendral Pengembangan Daerah Tertentu.

Direktorat Jendral Pengembangan Daerah Tertentu. (2018). Evaluasi 122 Kabupaten Tertinggal. Jakarta : Direktorat Jendral Pengembangan Daerah Tertentu.

El-Maaty, A. E., El-Hamrawy, S., \& Akal, A. Y. (2016). Management of Highway Projct in Egypt through Identifying Factor Influencing Quality Performance.

El-Maaty, A. E., El-Hamrawy, S., \& Akal, A. Y. (2016). Succes Factor of Highway Construction Projects in Egypt: AHP Approach.

Mwakajo, I. S., \& Kidombo, H. J. (2017). Factors Influencing Project Performance : A Case of Country Road Infrastructural Project in Manyatta Constutuency, Embu Counrty, Kenya. 2.

Nallathiga, R., Shaikh, H. D., Shaikh, T. F., \& Sheik, F. A. (2017). Factors Affecting the Success/Failure of Road InfrastructureProject Under PPP in India. 12.

Johnson R.A. and D.W. Wichern. (2007). Applied Multivariate Statistical Technique. Spinger. USA

Priyatno, D. (2011). Belajar Cepat Olah Data Statistik Dengan Spss. Yogyakarta: Cv. Andi Offset.

Project Management Institute . (2017). A Guide to the Project Management Body of Knowledge Sixth edition. Chicago: Project Management Institute .

Widoyoko,E. P. (2015). Buku Teknik Penyusunan Instrumen . Yogyakarta: Pustaka Pelajar

Santoso, S. (2017). Statistik Multivariat dengan SPSS. Jakarta: Elex Media Komputindo.

Sugiyono. (2015). Metode Penelitian Kuantitatif dan Kualitatif, dan R\&D. Jakarta: Alfabeta

Yao, \& Chen, S. (2014). The Predicament and Outlet of the Rule of Law in Rural Areas. 6.

Zachawerus, J., \& Soekiman, A. (2018). Faktor-Faktor yang Mempengaruhi Kesuksesan Peaksanaan Proyek Jalan Nasional di Maluku. 4.

Zulkifli, M. (2009). Validitas dan Reliabilitas Suatu Instrumen Penelitian. Jurnal Tabularasa PPS Unimed. Vol. 6, No. 1 